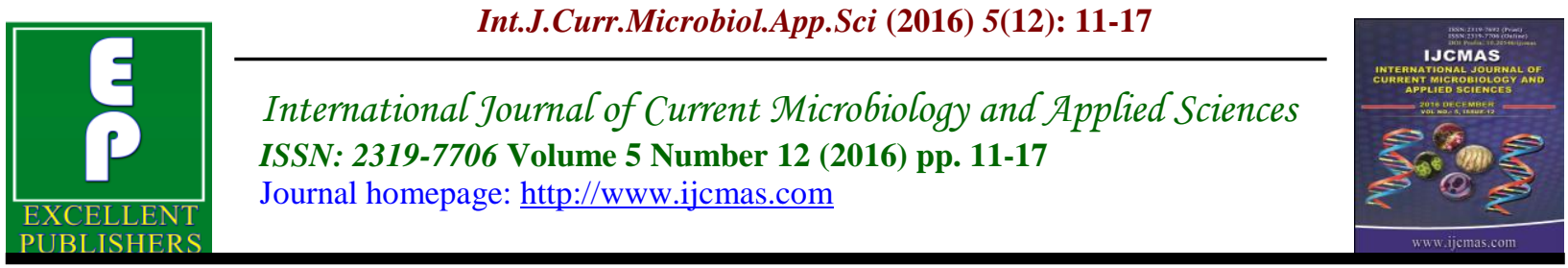

Original Research Article

http://dx.doi.org/10.20546/ijcmas.2016.512.002

\title{
Assessment of Serum Interleukin-33 Level in Psoriatic Patients
}

\author{
Abdel Aziz I. El-Taweel ${ }^{1}$, Fatma M. El-Sawy ${ }^{1}$, Omaima A. El Sayed ${ }^{2} *$ \\ and Nessma G.Z. Amin ${ }^{1}$ \\ ${ }^{1}$ Dermatology and Andrology, Faculty of Medicine, Benha University, Egypt \\ ${ }^{2}$ Microbiology and Immunology Department, Mansoura University, Egypt \\ *Corresponding author
}

\begin{abstract}
A B S T R A C T
Keywords

Psoriasis, enzyme-linked immunosorbent assay, interleukin 33.

\section{Article Info}

Accepted:

08 November 2016

Available Online:

10 December 2016

Psoriasis is a common chronic inflammatory skin disease affecting up to $2-3 \%$ of the population worldwide. Interleukin-33 is a recently discovered cytokine and one of the newest members that belongs to the IL-1 super-family inflammatory cytokines and is mainly expressed by different types of structural cells. IL-33 is considered an alarm molecule due to its release after necrosis or tissue damage. Psoriasis is associated with chronic inflammation and it often coexists with inflammatory arthritis in which IL-33 has been implicated. Assessment of serum IL-33 levels in psoriatic patients of different types and invistigate its correlation to the severity and extent of psoriasis.It is a case-control study, serum IL-33 levels were assessed by using commercial enzyme-linked immunosorbent assay kits (ELISA) in 40 psoriatic patients of different types (group I) and 30 apparaently healthy subjects as control (group II) with matched age and sex. A significant difference in IL-33 serum levels between patients and control was detected. Also positive correlation between IL-33 and Psoraisis Area and Sevirity Index (PASI) was detected. IL-33 could be considered as a reliable marker among different types of psoriasis and disease severity.
\end{abstract}

\section{Introduction}

Psoriasis is a multisystemic disease with predominantly skin and joint manifestations affecting approximately $2 \%$ of the population. The major manifestation of psoriasis is chronic inflammation of the skin. It is characterized by disfiguring, scaling, and erythematous plaques that may be painful or often severely pruritic and may cause significant quality of life (QOL) issues. Psoriasis is a chronic disease that waxes and wanes during a patient's lifetime, is often modified by treatment initiation and cessation and has few spontaneous remissions (Menter et al., 2008).

Interleukin (IL)- 33 is a cytokine of IL-1 family, which has been demonstrated to inducing cytokine synthesis and mediating inflammatory responses through its receptor suppression of tumorigenicity 2 (ST2) (Prey et al., 2010).

IL-33 can be classified as an alarmin because it is released into the extracellular 
space following cell damage or tissue injury and acts as an endogenous danger signal by sending out warning signals to alert neighbouring cells and tissues. It may be involved in psoriasis biology, and that its role could be via keratinocytes and mast cells (Liew et al., 2010).

Mitsui et al., (2015) investigated serum levels of IL-33 in psoriasis vulgaris (PV), psoriatic arthritis (PsA) and pustular psoriasis (PP), suggesting that serum IL-33 levels generally reflect increased inflammation in patients with psoriasis. The aim of this study was to assess serum IL-33 levels in psoriatic patients of different types and its value as a possible prognostic marker for disease severity.

\section{Patients and Methods}

\section{Subjects}

This a case-control study included 40 psoriatic patients (group I) and 30 apparaently healthy subjects were served as a control (group II) with matched age and sex was done in Dermatology and Andrology Clinic, Benha University Hospital during the period from December 2015 to November 2016.

\section{Group I (patients)}

The patients were randomly selected from the Outpatient Clinics of Benha University Hospital and Zagazig University Hospital.

\section{Group II (control)}

This group included 30 apparently normal healthy subjects with matched age and sex.

\section{Inclusion criteria}

Patients with all types of psoriasis. Patients 18 years and above.
Psoriasis Area and Severity Index (PASI ) $\geq 18$.

\section{Exclusion criteria}

Patients receiving systemic and local treatment for psoriasis within the past 4 weeks and 2 weeks respectively.

Patients taking steroids, immunosuppressive drugs, reciving PUVA treatment, receiving food supplements, vitamins, suffering from malnutrition, advanced liver or renal disease which may affect the serum interleukin 33 level

\section{Methods}

For every patient included in the study, the following items were fulfilled:

Detailed history including personal history, onset of disease, course and duration and possible medications.

PASI score to measure the severity and extent of psoriasis.

Distribution and morphology of lesions.

Complete dermatological examination.

Laboratory investigations including assessment of level of IL-33 by using commerical ELISA kits.

\section{Statistical analysis}

The collected data were tabulated and analyzed using SPSS version 16 soft ware (Spss Inc, Chicago, ILL Company) Categorical data were presented as number and percentages while quantitative data were expressed as mean \pm standard deviation, median and INTER QUARTILE range (IQR). Chi square test (X2), or Fisher's exact 
test (FET) were used to analyze categorical variables. Quantitative data were tested for normality using Kolomogrov Smirnove test, using Student " $t$ ", if normally distributed, or Man Whitney U test, Krauskal-Wallis test and Spearman's correlation coefficient (rho) if not normally distributed. ROC curve was used to determine cutoff value of IL-33 with optimum sensitivity and specificity in prediction of disease severity. The accepted level of significance in this work was stated at $0.05 \quad(\mathrm{P}<0.05$ was considered significant).

$\mathrm{p}$ value $>0.05$ is non significant (NS). $\mathrm{p}<$ 0.05 is significant $(\mathrm{S}) . \mathrm{p} \leq 0.001$ is highly significant (HS).

\section{Results and Discussion}

Table (1) showed the data structure, sample sizes and demographic characters of the studied samples. The most important data were age (years), sex, residence, smoking status, and BMI score $\left(\mathrm{kg} / \mathrm{m}^{2}\right)$. The overall mean of age in both cases and control groups was 42.3 years with \pm 9.9 . The overall BMI was found to be $28.8 \mathrm{~kg} / \mathrm{m}^{2}$ with \pm 4.7 . The ranges of both age and $\mathrm{BMI}$ were (20-60) years and (20-37) $\mathrm{kg} / \mathrm{m}^{2}$, respectively.

Table (2) showed the following:

No significance differences were detected as regard the age, BMI, sex, residence and smoking between patients and control $(\mathrm{P}>$ 0.05). Significance difference was detected only regarding the family history $(\mathrm{P} \leq 0.05)$.

Table (3) showed the classification of clinical data of the studied patients with qualitative and quantitative variables. The mean value of PASI score was 21.6 with SD of 4.7. Moreover, the range of PASI score was varied between 18 and 32 .
Table (4) showed a highly significant differance $(\mathrm{P} \leq 0.001)$ between patients and control regarding IL-33.

Table (5) showed a significant difference ( $\mathrm{P}$ $\leq 0.05)$ in IL-33 serum level between moderate and severe cases.

Figure (1) positve correlation coefficient between IL-33 and PASI. The correlation between IL-33 and PASI $(\mathrm{P} \leq 0.05)$.

Figure (2) Showed ROC curve for IL-33 performance as a prognostic marker for disease severity in psoraisis.IL-33 was a good prognostic marker as the $\mathrm{AUC}=0.73$.

Psoriasis is a chronic inflammatory disease with polygenic predisposition combined with triggering environmental factors such as trauma, infection and medications. IL-33 is secreted from fibroblasts under mechanical strain in the absence of necrosis, demonstrating that IL-33 could exit the cell in response to mechanical strain, similar to other damage-associated molecular patterns (DAMPs), such as IL-1b in keratinocytes.

In the present study, serum IL-33 levels were assessed in 40 psoriatic patients and different types. Also, value of IL-33 was assessed as a possible prognostic marker for disease severity.

The age of patients in this study ranged from 20 to 60 years old within male and female. The mean of age in patients was $42.9 \pm 11.4$. This showed that psoriasis may occur in any age.

However, Henseler and Christophers (1985) detected the bimodal distribution of psoriasis incidence representing two clinical presentations of the disease; type I (early onset) and type II (late onset). 
Although sex association with patients was non-significant, Tollefson et al., (2010) suggested the potential role of sex hormones in the etiology of psoriasis. Furthermore, it appeared that the incidence of psoriasis was higher in females $<18$ years old but was higher in males $\geq 18$ years old.

The family history was tested statistically in this study and indicating a significant relationship. Barrett et al., (2009) showed that psoriasis has a genetic component based on studies done in different populations. This study suggested that psoriasis is a multifactorial or polygenetic disease that is influenced by both genetic and environmental factors. Linkage and association studies have found a major susceptibility locus called psoriasis susceptibility locus 1 (PSORS1).

The correlation between IL-33 serum level and BMI was non significant. Although, Prey et al., suggested that psoriasis patients are more frequently overweight or obese than the general population. Also, severity and psoriasis may be correlated to BMI as obesity can induce overproduction of multiple pro-inflammatory cytokines in adipose tissue, including TNF- $\alpha$, IL-6, IL-8 and reactive C-protein which are implicated in the pathogenesis of psoriasis.

This study showed a significant difference between patients and controls regarding serum levels of IL-33.

Tamagawa-Mineoka et al., (2014) showed that serum IL-33 levels were greatly increased in patients with Th-2-mediated atopic dermatitis, and were slightly raised in patients with psoriasis. In patients with rheumatoid arthritis, both serum and synovial fluid, IL-33 levels are higher than those in osteoarthritis, probably due to the increased IL-33 release from human fibroblasts in the synovial fluid and patients with RA.

Table.1 Socio-demographic characters of the studied groups.

\begin{tabular}{|c|c|c|c|}
\hline & Variables & No. $(\mathrm{N}=70)$ & $\%(100 \%)$ \\
\hline \multirow[t]{2}{*}{ The studied groups } & Patients & 40 & 57.1 \\
\hline & Control & 30 & 42.9 \\
\hline \multirow[t]{5}{*}{ Age (years) } & $20-30$ & 6.0 & 8.6 \\
\hline & $>30-40$ & 24 & 34.3 \\
\hline & $>40-50$ & 22 & 31.4 \\
\hline & $>50-60$ & 18 & 25.7 \\
\hline & Mean \pm SD (Range) & \multicolumn{2}{|c|}{$42.3 \pm 9.9(20-60)$} \\
\hline \multirow[t]{2}{*}{ Sex } & Male & 50 & 71.4 \\
\hline & Female & 20 & 28.6 \\
\hline \multirow[t]{2}{*}{ Residence } & Benha & 26 & 37.1 \\
\hline & Zagazig & 44 & 62.9 \\
\hline \multirow[t]{2}{*}{ Smoking } & Yes & 26 & 37.1 \\
\hline & No & 44 & 62.9 \\
\hline \multirow[t]{4}{*}{ BMI $\left(\mathrm{kg} / \mathrm{m}^{2}\right)$} & Normal weight $(18.5-24.9)$ & 18 & 25.7 \\
\hline & Overweight $(25: 29.9)$ & 19 & 27.1 \\
\hline & Obesity $(\geq 30)$ & 33 & 47.1 \\
\hline & Mean \pm SD (Range) & \multicolumn{2}{|c|}{$28.8 \pm 4.7(20-37)$} \\
\hline
\end{tabular}


Table.2 Comparing patients and control regarding age, BMI, sex, residence, smoking and family history

\begin{tabular}{|c|c|c|c|c|c|c|c|}
\hline \multirow{2}{*}{\multicolumn{2}{|c|}{ Variable }} & \multicolumn{2}{|c|}{ Patients $(\mathrm{N}=40)$} & \multicolumn{2}{|c|}{ Control $(\mathrm{N}=30)$} & \multirow[b]{2}{*}{ St."t" } & \multirow[b]{2}{*}{$\mathrm{P}$} \\
\hline & & Mean & \pm SD & Mean & $\pm \mathrm{SD}$ & & \\
\hline \multicolumn{2}{|c|}{ Age (years) } & 42.9 & 11.40 & 41.4 & 7.59 & 0.61 & $\begin{array}{l}0.54 \\
\text { (NS) }\end{array}$ \\
\hline \multirow{2}{*}{\multicolumn{2}{|c|}{ BMI $(\mathrm{kg} / \mathrm{m} 2)$}} & 29.02 & 5.00 & 28.5 & 4.29 & 0.44 & $\begin{array}{l}0.66 \\
\text { (NS) }\end{array}$ \\
\hline & & No. & $\%$ & No. & $\%$ & $\mathrm{X2}$ & $\mathbf{P}$ \\
\hline \multirow{2}{*}{ Sex } & Male & 26 & 65.0 & 24 & 80.0 & \multirow{2}{*}{1.89} & \multirow{2}{*}{0.17 (NS) } \\
\hline & Female & 14 & 35.0 & 6 & 20.0 & & \\
\hline \multirow{2}{*}{ Residence } & Benha & 17 & 42.5 & 9 & 30.0 & \multirow[t]{2}{*}{1.15} & \multirow[t]{2}{*}{$0.28(\mathrm{NS})$} \\
\hline & Zagazig & 23 & 57.5 & 21 & 70.0 & & \\
\hline \multirow{2}{*}{ Smoking } & Yes & 14 & 35.0 & 12 & 40.0 & \multirow[t]{2}{*}{0.18} & \multirow{2}{*}{$0.66(\mathrm{NS})$} \\
\hline & No & 26 & 65.0 & 18 & 60.0 & & \\
\hline \multirow[t]{2}{*}{ family history } & Positive & 9 & 22.5 & 1 & 3.3 & \multirow{2}{*}{ FET was used } & \multirow[b]{2}{*}{$0.036(\mathrm{~S})$} \\
\hline & Negative & 31 & 77.5 & 29 & 96.7 & & \\
\hline
\end{tabular}

Table.3 Clinical data of the studied patients

\begin{tabular}{|l|l|c|c|}
\hline \multicolumn{2}{|c|}{ Variable } & No. $(\mathrm{N}=40)$ & $\%(100 \%)$ \\
\hline \multirow{2}{*}{ Severity } & Moderate & 30 & 75.0 \\
\cline { 2 - 4 } & Severe & 10 & 25.0 \\
\hline \multirow{3}{*}{ PASI score } & Mean \pm SD & \multicolumn{2}{|c|}{$\mathbf{2 1 . 6 \pm 4 . 7}$} \\
\cline { 2 - 4 } & Range & \multicolumn{2}{|c|}{$\mathbf{1 8 - 3 2}$} \\
\hline \multirow{5}{*}{ Duration (years) } & $1-2$ & 4 & 10.0 \\
\cline { 2 - 4 } & $>2-3$ & 8 & 25.0 \\
\cline { 2 - 4 } & $>3-4$ & 18 & 45.0 \\
\cline { 2 - 4 } & $>4$ & 7 & 17.5 \\
\hline \multirow{2}{*}{ Affected joints } & Yes & 33 & 82.5 \\
\cline { 2 - 4 } & No & \multicolumn{2}{|c|}{} \\
\hline
\end{tabular}

Table.4 Comparing the studied groups regarding serum levels of IL-33.

\begin{tabular}{|l|c|c|c|c|c|c|c|c|}
\hline Parameter & \multicolumn{3}{|c|}{ Patients (N=40) } & \multicolumn{3}{c|}{ Control (N=40) } & $\begin{array}{c}\text { Z of } \\
\text { MWU test }\end{array}$ & $\begin{array}{c}\text { P- } \\
\text { value }\end{array}$ \\
\cline { 2 - 8 } & Mean & \pm SD & $\begin{array}{l}\text { Median \& } \\
(\text { IQR })\end{array}$ & Mean & \pm SD & $\begin{array}{l}\text { Median \& } \\
(\text { IQR })\end{array}$ & 1.24 \\
\hline IL-33 & 1.72 & 0.73 & $\begin{array}{c}1.43 \& \\
(1.31-1.86)\end{array}$ & 1.24 & 0.45 & $\begin{array}{c}1.2 \& \\
(1.08-1.47)\end{array}$ & 3.25 & $\begin{array}{c}0.001 \\
(\mathrm{HS})\end{array}$ \\
\hline
\end{tabular}


Table.5 Levels of serum IL-33 according to the severity of psoriasis among patients group.

\begin{tabular}{|c|c|c|c|c|c|c|}
\hline \multirow{2}{*}{ Variable } & \multicolumn{2}{|c|}{ Moderate $(\mathrm{N}=30)$} & \multicolumn{2}{|c|}{ Severe $(\mathrm{N}=10)$} & \multirow{2}{*}{ Z of MWU test } & P-value \\
\cline { 2 - 7 } & Mean & $\pm \mathrm{SD}$ & Mean & $\pm \mathrm{SD}$ & & \\
\hline IL-33 & 1.53 & 0.45 & 2.29 & 1.07 & 2.16 & $0.031(\mathrm{~S})$ \\
\hline
\end{tabular}

Fig.1 Correlation between IL-33 and PASI.

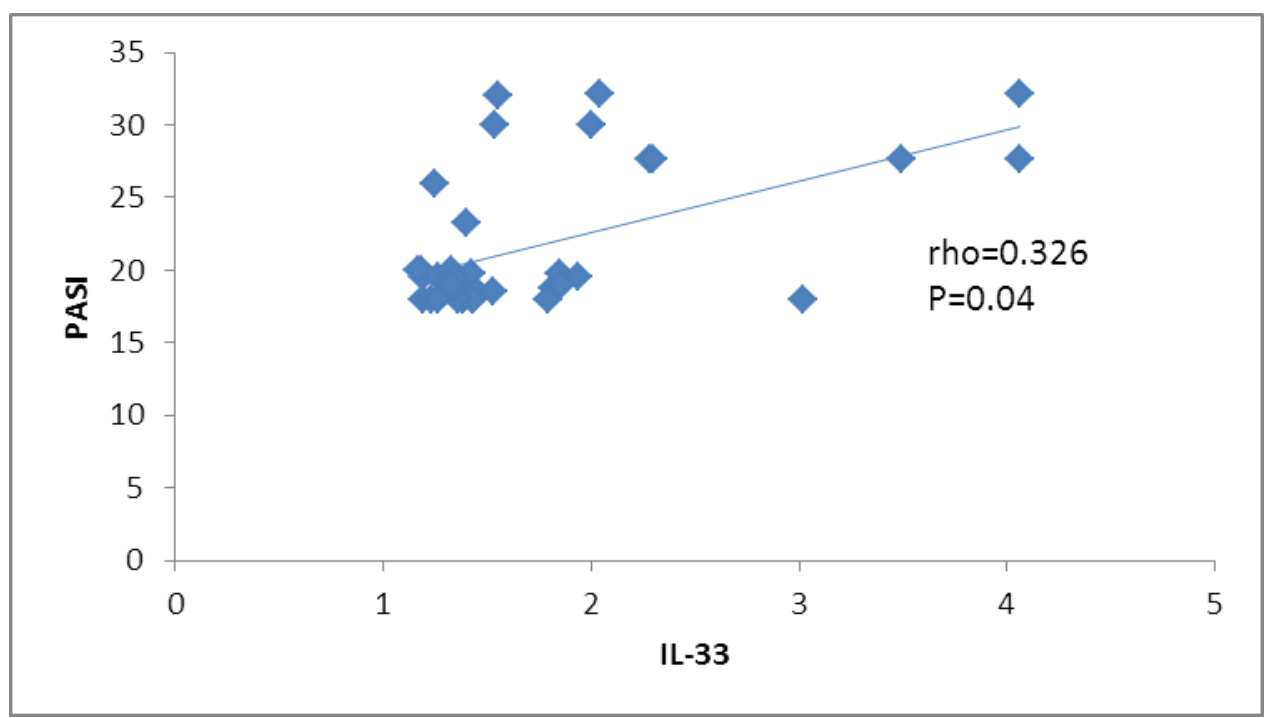

Fig.2 ROC curve for IL-33 performance as a prognostic marker for disease severity in psoriasis (performance in differentiating moderate from severe forms)

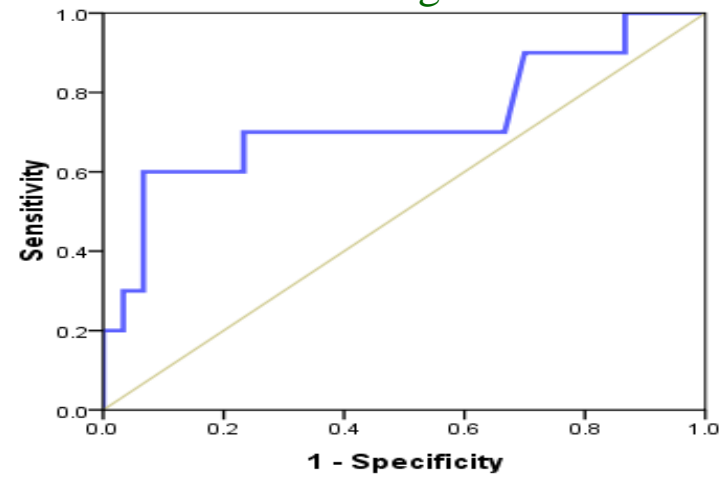

Theoharides et al., (2010) showed that IL-33 stimulation secrete VEGF. Furthermore, IL33 mRNA expression is increased along with Histidine Decarboxylase (HDC), an indicator of mast cell presence/activation, in psoriatic skin. They reported that interactions among Substance P, IL-33 and mast cells may be important in inflammatory diseases where there is excessive angiogenesis, such as psoriasis. So IL-33 may represent novel therapeutic target.
Verri et al., (2010) showed that serum IL-33 levels in patients with psoriasis were correlated significantly with serum TNF- $\alpha$ levels and decreased significantly after antiTNF- $\alpha$ therapy. Serum levels of IL-33 decreased after administration of anti-TNF- $\alpha$ agents in both ulcerative colitis and RA. Injection of IL-33 into mouse ear recruits neutrophils to injection site. Positive correlation was detected in our study 
between IL-33 serum levels in patients and PASI $(p \geq 0.05)$.

These findings were supported by Mitsui et al., (2015) who investigated serum levels of IL-33 in PV, PsA and pustular psoriasis and suggested that serum IL-33 levels generally reflect increased inflammation in patients with psoriasis.

In conclusion, IL-33 could be considered as reliable marker in diagnosis of psoriatic patients and for increasing disease severity. As IL-33 has multiple effects in aggravating inflammation, such as activation of neutrophils, mast cells and keratinocytes, the results might therefore partly explain the mechanism for TNF-a inhibitor efficacy in patients with psoriasis.

\section{References}

Barrett, J.C., Lee, J.C., Lees, C.W., Prescott, N.J., Anderson, C.A., et al. Genome-wide association study of ulcerative colitis identifies three new susceptibility loci, including the HNF4A region. Nature genetics, 41(12): 1330-4.

Henseler, T., Christophers, E. 1985. Psoriasis of early and late onset: characterization of two types of psoriasis vulgaris. J. Am. Acad. Dermatol., 13: 450-6.

Liew, F.Y., Pitman, N.I. and McInnes, I.B. 2010. Disease-associated functions of IL-33: the new kid inthe IL-1 family. Nat. Rev. Immunol., 10: 103-10.

Menter, A., Gottlieb, A., Feldman, S.R., Van Voorhees, A.S., Leonardi, C.L., et al. 2008. Guidelines of care for the management of psoriasis and psoriatic arthritis: Section 1. Overview of psoriasis and guidelines of care for the treatment of psoriasis with biologics. J. Am. Acad. Dermatol., 58(5): 826-50.

Mirchandani, A.S., Salmond, R.J. and Liew, F.Y. 2012. Interleukin-33 and the function of innate lymphoid cells. Trends Immunol., 33: 389-96.

Mitsui, A., Tada, Y., Takahashi, T., Shibata, S., Kamata, M., et al. 2015. Serum IL-33 levels are increased in patients with psoriasis. Clin. Exper. Dermatol.

Prey, S., Paul, C. and Bronsard, V. 2010. Cardiovascular risk factors in patients with plaque psoriasis: a systematic review of epidemiological studies. JEADV, 24: 23-30.

Tamagawa-Mineoka, R., Okuzawa, Y., Masuda, K. and Katoh, N. 2014. Increased serum levels of interleukin 33 in patients with atopic dermatitis. J. Am. Acad. Dermatol., 70: $882-8$.

Theoharides, T.C., Zhang, B. and Kempuraj, D. 2010. IL-33 augments substance Pinduced VEGF secretion from human mast cells and is increased in psoriatic skin. Proc. Natl. Acad. Sci. USA, 107: 4448-53.

Tollefson, M.M., Crowson, C.S., McEvoy, M.T. and Maradit Kremers. H. 2010. Incidence of psoriasis in children: A populationbased study. J. Am. Acad. Dermatol., 62(6): 979-87.

Verri, W.A. Jr, Souto, F.O., Vieira, S.M., Almeida, S.C., Fukada, S.Y., et al. 2010. IL-33 induces neutrophil migration in rheumatoid arthritis and is a target of antiTNF therapy. Ann. Rheum. Dis., 69: 1697-703.

\section{How to cite this article:}

Abdel Aziz I. El-Taweel, Fatma M. El-Sawy, Omaima A. El Sayed and Nessma G.Z. Amin. 2016. Assessment of Serum Interleukin-33 Level in Psoriatic Patients. Int.J.Curr.Microbiol.App.Sci. 5(12): 11-17. doi: http://dx.doi.org/10.20546/ijcmas.2016.512.002 